\title{
Religious Extremism and Tolerance in Africa: Negotiating Terrorism through Religious Diaconia?
}

\author{
Dr Obaji M. Agbiji ${ }^{1}$, and Dr Emem Agbiji ${ }^{2}$ \\ ${ }^{1}$ Post-Doctoral Research Fellow, Research Institute for Theology and Religion (RITR), University of South \\ Africa (UNISA), South Africa \\ ${ }^{2}$ Post-Doctoral Research Fellow, Department of Philosophy, Practical and Systematic Theology, University of \\ South Africa (UNISA), South Africa
}

\begin{abstract}
The spate of religious violence in African countries such as Nigeria and Kenya by Islamic militants has taken a new turn in recent years. The new waves of violence now includes the use of sophisticated strategies and weapons of mass destruction by well-trained agents of terror such as Boko Haram and Al-Shabaab drawn from within Africa and beyond to gain socio-political and economic power, convert non-Muslims to Islam and to establish Islamic Caliphates. Through Ninian Smart's phenomenology of religion and the concept of religious (Christian) diaconia, this paper interrogates the factors that have given rise to Islamic militant groups, the dilemma of religious communities in response to the crisis and further explores appropriate religious strategy(ies) that could ameliorate Islamic militancy in Africa.
\end{abstract}

Keywords: Religious extremism, Religious tolerance, Terrorism, Diaconia, Africa, Boko Haram, Al-Shabaab, Nigeria, Kenya

\section{Introduction}

Religious conflicts and tensions between two of the three major religions in Africa namely Christianity and Islam have been common place in especially Nigerian and Kenyan history. However, a new wave of religious violence in the form of terrorism has been initiated by Boko Haram in Nigeria and Al-Shabaab in Kenya in an exponential magnitude that can be described as unprecedented (Mwakimako 2007:289; Cook 2011:3). The patterns of violent attacks by Islamist terrorists groups such as Boko Haram in Nigeria and Al-Shabaab in Kenya indicates the existence of established contacts between these African terrorist groups and global terrorist groups such as Al-Qaeda. The resolve to unleash mayhem (such as the catastrophe of September 11, 2001 at the world trade center in the United States) with sophistication indicates that these terrorist groups are driven by similar ideologies (Cook 2011:1-3; Obadare 2004:178). These terrorist activities are mostly aimed at Christians. This unprecedented violence could be argued as an attempt to undermine Christianity so as to pave the way for the Islamization of Nigeria and Kenya. Of greater concern in Nigeria is the fact that these activities aimed at Christians are well orchestrated and enjoy the support of Muslim politicians, businessmen/women, security officers, global terror groups and some Islamic countries (Zenn 2014:23, 26; Olojo 2013:11). The Christian community and political institutions in Africa appear to be in a quandary in finding appropriate steps to contain the crisis (Olojo 2013:1; Nzwili 2012; Dachs 2014).

The decision to reflect on the terrorist activities of Boko Haram and Al-Shabaab in this paper is informed by inferences being drown from the experiences of these two African countries in the public debate on terrorism in Africa (Nzwili 2012; Omayio 2015:41,42).

In engaging the concept of Diaconia, we intend to interrogate the response of the Church in Nigeria and Kenya to this new wave of Islamic militancy as presented by Boko Haram and Al-Shabaab. The following questions are crucial to this paper: What factors have contributed to the rise of Boko Haram and Al-Shabaab in Nigeria and Kenya respectively? So far, how has the Church responded to the challenge of these groups which have a direct impact on her existence and well-being? How may the Church's diaconal ministry mitigate the challenges being posed by these terrorist groups and other forms of militant Islam in Nigeria and Kenya? 
This paper will be informed by Ninian Smart's (1996) phenomenological paradigm of religion in the sociology of religion. Smart opines that power animates the various dimensions of religion. As such the will to appropriate the absolute power of God drives religious leaders and especially preachers who see themselves and are seen by their followers as following in the footsteps of prophets of monotheistic religions (Islam, Christianity and Judaism) (Smart 1996; cf. Popular Discourses of Salafi Radicalism and Salafi Counter-radicalism in Nigeria, hereafter Popular Discourses 2012:119).. Smart's phenomenological paradigm of religion could therefore illuminate on the reasons that have given rise to Boko Haram and Al-Shabaab and their ideology given the prevailing arguments touching on the rise of the groups as presented by some scholars and social commentators. The phenomenological paradigm could also account for the motivations of the leaders and members of Boko Haram and Al-Shabaab, and why they are inclined to religious intolerance, being audacious and arrogant in attacking Christians and socio-political institutions in Nigeria and Kenya.

In this paper we define religious tolerance as implying a willingness to 'put up with' the religious beliefs and cultures of other persons that share the same socio-political context with us even when our religious opinions and dogmas vary (cf. Hobolt et al. 2011: 3,4). On the other hand religious extremism or intolerance is the willingness of religious persons who subscribe to certain religious systems and doctrines believed to be sanctioned by God to murder or cause harm to other persons who subscribe to other religious systems and beliefs with the understanding that such acts of violence are in the service of God. Religious extremism is synonymous to religious terrorism. Extremists or terrorists have no sympathy for their victims, because they view those victims as enemies of God and they readily sacrifice their own lives because they expect huge and immediate afterlife rewards in return for martyrdom (Iannaccone \& Berman 2006:109).

Following then our introductory discussion, we will first address the rise of Boko Haram and Al-Shabaab as deadly and very sophisticated wings of militant Islam. Secondly, we will interrogate what steps the Church has taken so far in addressing the challenges being posed by Boko Haram and Al-Shabaab. Thirdly, we will explore if and how the Church's diaconal ministry could contribute towards a more meaningful response to the menace of Boko Haram and Al-Shabaab.

\section{The Rise of Islamic Militancy in Africa}

Our discussion on the rise of Islamic militancy in Africa with particular reference to Boko Haram and AlShabaab will be considered on the premise of a tentative exploration due to available space when compared to the burgeoning literature on the subject of Islamic terrorism in Africa. The intention is at least to first set a background that takes into account the basic factors that have given rise to these groups. Secondly, the account is to set the basis for the appraisal of the church's response to the crisis and the basis for which further steps can be undertaken in addressing the crisis. The discussions on these groups often centre on the origin of the groups and the socio-political, economic and religious factors that account for their emergence in Nigeria and Kenya (Olojo 2013; Popular Discourses 2012:120; Otiso 2009; Mwakimako 2007).

\subsection{The rise of Boko Haram in Nigeria}

Jama'atu Ahlis Sunna Lidda'awati Wal-Jihad ${ }^{1}$ popularly known as Boko Haram can be seen in the broader context of Islamic movements that espouses unorthodox beliefs and unconventional religious practices. These groups are often linked to ethnic and religious violence in Nigeria, most notably the Maitatsine group active in the 1980s (Popular Discourses 2012:120). Although Boko Haram came to public notice in Nigeria in 2009, the origin of the group can be traced to 1995 (Mohammed 2014:9). Its initial emergence was as a Muslim youth organisation called Shabaab, under the leadership of Lawan Abubakar and later Mohammed Yusuf, with its headquarters in Maiduguri, Borno State, in north-eastern Nigeria. Until the death of Yusuf in 2009, Ibrahim Shekau the present leader of Boko Haram was the deputy leader of the group (Zenn 2014:23). It is believed that the initial membership of the group comprised Muslim students from the University of Maiduguri who dropped out of school in response to the preaching of a foreign Islamic scholar who convinced them that Western

\footnotetext{
${ }^{1}$ Boko Haram identifies itself as Jama'atu Ahlis Sunna Lidda'awati Wal-Jihad, which means "People Committed to the Propagation of the Prophet's Teachings and Jihad" in Arabic.
} 
education was haram (unlawful) in Islam (Olojo 2013:2,3). When translated from Hausa to English Boko Haram means "Western education is sinful".

Several factors have been articulated with regards to the rise of Boko Haram which have merit and cannot be ignored including structural factors such as socio-cultural systems, political structures and socio-economic factors including poverty, unemployment, economic marginalisation, discrimination, group grievances and illiteracy (Olojo $(2013: 1,2)$ which are used as mobilising factors by dangerous persons or groups to find support for terrorism in Northern Nigeria (Jonnie Carson 2012; Harnischfeger 2014:35). But it could also be argued that poverty and socio-economic problems are not affecting only the Muslim youths of northern Nigeria. Christian youths from Northern Nigeria and other parts of the country face similar challenges. Besides, why has the demand for the institutionalisation of sharia system and the rise of Boko Haram only been witnessed when a Christian is occupying the position of president of the nation? In addition, what connection does the church have with the disparity between the rich and the poor and the failure of the state to address the economic challenges of her citizens to attract the anger of the Muslim youths against her? Or could it be based on what Ogbu Kalu (2010) has termed the theory of social suffering - a case of misappropriated anger, which instead of the poor directing their frustration on the structures that keep them down, they take it on the religious other?

Mohammed (2014:23) has argued that besides internal factors such as mentioned above, the drivers of Islamic militancy in Nigeria also include external political, colonial and religious factors. He insists that these external factors have made a greater contribution to the crisis. Whilst these external factors such as colonialism and the war against terrorism impinge on the sentiment of Western domination over the non-western world, it also feeds the religious sentiments of the Muslim world including the Muslim youths of northern Nigeria as a domination of Christianity over Islam. Based on this perception, Boko Haram, its members and supporters see themselves as rising in defence of Islam especially in the restoration of the Caliphate founded by Usman dan Fodio and joining forces with the Muslim Ummah in fighting Jihad against the western world and its Christian allies in Nigeria (Harnischfeger 2014:43, 47,51 cf. HRW 2012:26,30).

Therefore, some scholars insist that the nucleus of the ideology of Boko Haram and indeed other forms of Islamic militancy in Nigeria is religious (Agbiboa 2013: 8; Mohammed 2014:23). Other drivers which are assumed to be socio-political and economic are merely engaged to score a religious point or used to give impetus to a religious agenda (Agbiboa 2013: 8). This conclusion is reached in consideration of the statements of the leaders of Boko Haram, who insist on the religious motives of their insurrection: "This is a war between Muslims and non-Muslims...This is not a tribal war, nor is it ... a war for financial gains, it is solely a religious war" (Harnischfeger 2014:35). The message of Boko Haram was articulated by its leader Mohammed Yusuf whose teachings were derived from and reflect the extant discourse and ideology of radical Islamism worldwide, in rejection of secularism, democracy, Western education and Westernisation secularism and the pursuit of its replacement by Shariah (Mohammed 2014:15). His teachings urged the members to lay down their lives and resources to the endeavour and assured them of victory and eternal reward from Allah. As a result of his teachings Boko Haram has carried out numerous violent attacks on churches and Christians in North and central Nigeria between 2009 till date which involves killings of Christians, destruction of properties and rape etc. On many occasions lasting for days which is well documented in literature and cannot here be dealt with in details because of limited space (HRW 2012:44,45; Pretorius 2013:209; (Zaimov 2014).

Yusufu's teachings affirms Smart's theory that he has taken on himself the position of the powerful other (divinity) to fight for him/her as the Prophet did (cf. Smart 1996; Popular Discourses 2012:119). From the views of scholars and social commentators, it appears that Christians in Nigeria are facing enormous persecution and martyrdom from the hands of Muslims and Boko Haram. Above all, Boko Haram appears to have declared war against Christians and they seem to be employing all of their resources derived from within and outside of Nigeria to achieve their jihadist agenda. But a similar scenario is also being witnessed in Kenya where AlShabaab appears to be on a rampage.

\footnotetext{
${ }^{2}$ Abubakar Shekau the leader of Boko Haram in a video message, in (Anon.), "Jos Bombing: Text of video Statement by Jama'atu Ahlus-Sunnah Lidda'awati Wal Jihad”, Elombah, 28 December 2010.
} 


\subsection{The rise of Islamic terrorism in Kenya}

Although Kenya has witnessed various waves of terrorism historically such as ethno-nationalist or separatist, the current religious or "sacred" terrorism such that is perpetrated by Al Qaeda and its affiliate organisation AlShabaab, is currently operational in the country (Otiso 2009:108,109). The engagement of native Muslim Kenyans in the terrorist activities of Al-Shabaab has been attributed by public commentators to the development of many Salafi religious institutions in eastern Africa in the middle of the last century by Saudi Arabia. The outposts took off in Sudan and Somalia, where Muslim-majority populations were governed by dictatorial regimes (Meleagrou-Hitchens 2013). These two countries became hubs of Salafi teaching, with Sudan in particular becoming a popular destination for Kenyan Sufi sheikhs seeking training. Many of these Sufi sheikhs returned home to Kenya as Salafis (Meleagrou-Hitchens 2013). One of such Salafi was Aboud Rogo. Rogo was able to establish himself as one of the leading Salafi preachers in Kenya. By the 1990s, he established ties with jihadists around the world Meservey has argued that terrorist activities in Kenya that are specifically targeted at Christians are no longer a new development. Since October 2011, Al-Shabaab has launched more than 100 attacks inside Kenya that have claimed hundreds of lives and sent the country's tourism industry into a tailspin. Many of the attacks have been as ruthless as the attack on the Westgate Mall in Nairobi in September 2013, that of a Kenyan town in June 2014 and that of Garrisa University where non-Muslims were systematically executed (Meservey 2015 cf. Kigotho 2015).

The Westgate shopping centre attacks in Nairobi, Kenya ranks as one of Al-Shabaab's high profile operations within the shores of Kenya. In this attack, non-Muslims were targeted when Islamic militants stormed a shopping mall in the worst terrorist attack Kenya has suffered since the US embassy bombings in east Africa in the 1990s (Meleagrou-Hitchens 2013). In a bid to consolidate its power in Somalia, Al-Shabaab's activities centred on power struggle within the group, raiding villages and terrorizing local populations. In Somalia especially, most of Al-Shabaab's victims were Muslims - including many Al-Shabaab fighters themselves. The approach whereby leadership is acquired and sustained in Al-Shabaab is in line with Smarts' argument that the drive for power animates religious leaders and could well be the reason for religious extremism and terror in Kenya as in Nigeria. Also, this disposition of Al-Shabaab terrorising fellow Muslims runs contrary to the much touted ideology of jihad against western countries and Christians. It portrays the power interest vested in the ideologies of the leadership of the organisation to build a caliphate which they govern. While corruption, injustice, abuse, disillusionment and marginalization are among factors that have given rise to Islamic militancy in Kenya, religious fundamentalism, religious intolerance and the quest for power are the core factors that have given rise to terrorism in Kenya and other parts of Africa such as Nigeria. The years of rampage of Boko-Haram and Al-Shabaab in Nigeria and Kenya respectively can no longer be ignored. If sustainable measures are not put in place by political but also religious institutions such as the Church to address these crises in these two countries, but also the west and east African regions, there is concern that these entities will soon become even more unstable (Hidalgo 2015).

\section{The Response of the Church to Islamic Militancy in Africa}

In this study, we will use the term church and Christians interchangeably and in a generic sense. The term church will also be used in reference to the various expressions of the communities of the followers of Jesus as regards congregations, denominations and inter-denominational collaborations (ecumenical formations) for the purpose of worship and witness (Agbiji 2012:20; Hughes \& Bennett 1998:72; de Gruchy 1994:126; Onwunta 2006:140). The response of the Nigerian and Kenyan Church to Islam militancy including Boko Haram and AlShabaab can be summarised into five categories namely: prayer, relief/social services, inter-religious dialogue, advocacy and retaliation.

Christian leaders and churches in Nigeria and Kenya have responded to Islamic militancy through prayers to God for the protection of the citizens against terrorism, comfort for affected persons, and exposure of members and supporters of the group. Such prayers are also directed at the terror group for a change of heart on the part of its members so that peace and harmony will be restored to the Nigerian and Kenyan society (Otubu 2014; Lodge 2015; Catholic Herald 2015).

Church leaders, through the Christian Association of Nigeria (CAN), National Council of Churches in Kenya (NCCK), Anglican Development Services (ADS) and Diakonia have also played key roles in the area of 
relief and social services (Agbiji 2012:119,120; Agbiji 2013:;Githaiga 2013). Such provisions usually include food, shelter, clothing, trauma counselling and medical care immediately while reaching out to the various levels of the ecumenical church organisation for more support. These services have provided much needed succour in critical times(Agbiji 2013) when the Nigerian and Kenyan governments have often been found wanting (Agbiji 2012:118).It is often through such measures that Christians have contributed towards the rehabilitation of ordinary Nigerians and Kenyans who have suffered huge losses because of these crises (Agbiji 2012:119,120; PCN Communiqué 2014:13; Githaiga 2013).

The perennial challenge of Islamic fundamentalism in Nigeria and Kenya, which has brought about colossal destruction of human lives and property in the two countries, has given impetus to the need for dialogue. John Cardinald Onaiyekan (2010:7), immediate past president of CAN, Catholic Archbishop of Abuja and immediate past co-chairman of the Nigerian Inter-religious Council (NIREC), asserts that "inter-religious dialogue is perhaps the best way to describe what we understand by management of our religious diversities". It is to the credit of Nigerian and Kenyan church leaders, that the initiative to engage in dialogue with Islamic leaders constitutes such a giant step towards peace building amongst the two religions and the socio-political and economic development of their societies (Agbiji 2012:121; CAN 2004:2; CAN 2010: 15; Abubakar 2010:1; America 2004:6; Omayio 2015:41; 2014:68).

In addition to religious dialogue, Christian religious leaders operating under the auspices of CAN for instance, are of the view that 'the most important political duty which CAN often performs is its warning and prophetic function' (CAN 2010:13). They are in the main engaged in advocacy through communiqués, press releases and messages from both the pulpit and the mass media. As part of this development, it is significant to observe how it has become characteristic of denominational and ecumenical church bodies to issue public statements at the conclusion of their major meetings and after terror attacks - i.e. statements that relate to socioreligious, economic and political issues (Agbiji 2012:128; CAN 2012; Williams 1988:11; CAN 1988:9-12; Omayio 2015:41; 2014:68). . It is this 'warning and prophetic function' that could play an important advocacy role in the transformation of Nigerian society. church leaders have often reminded both the government and Nigerian society of the precarious conditions prevailing in Nigeria such as Islamic terrorism, and in the process have challenged Nigerian leaders to rise to the challenges of Islamic militancy against Christians and the Nigerian society, poverty, unemployment, human rights abuses, the political crisis, criminal activities and the general insecurity of the nation (CAN 2014a; CAN 2014b; CAN 2014c; CAN 1988:48-50; Mbachirin 2004:654). In addition to press conferences, Kenyan churches respond to terrorism through protests which are intended to pressurise the government to respond more adequately to the acts of terrorism (Dachs 2014).

In contemporary Nigeria, a large number of Christians point to issues of political dominance and violence as the motives of Islam in Northern Nigeria, ultimately aimed at stretching the frontiers of Islamic aggression to other parts of the country (Mang 2014:90). This perceived threat although interpreted differently within the Christian community in Nigeria, has resulted in violent responses to Islamic terrorism on the part of some Christians (Mang 2014:90; Kwashi 2004:65). In Kenya, Christians have not responded violently. There is however an increasing concern that should these attacks continue and should the government and security operatives continue to fail in adequately responding to the crisis, they might resort to violent response (Omayio 2015:41,42; Nzwili 2012).

Yet, R. Niebuhr has warned that the religious person can be tempted to claim divine sanction for very human and harmful actions. They can be tempted to equate their particular interests with eternal truth (Niebuhr 1937, Cited in Graybill 1995). Niebuhr's warning could be assumed to be calling to question the extra-judicial actions of Islamic terrorists who lay claim to a divine mandate and Christian extremists who also kill in self-defence based on a theological stance.

It could be argued that the response of the church so far to religious terrorism has been majorly reactionary than proactive. It is however doubtful if the church has exhausted its resources in its quest for a sustainable presence and witness in the Nigerian and Kenyan society. But it could be argued that in addition to the existing avenues of engagement with the ongoing challenge of Islamic militancy as mentioned above, the various expressions of the church (ecumenical, denominational, congregational and personal) could still evolve other strategies that will not just assist the church to "survive the crisis", but such measures that could enhance the church's witness and could forestall the re-occurrence of similar crisis in the future. Above all, a strategy that is inherently entrenched in the very nature of the church could place the church on a vantage position to blossom through the transformation of crisis to opportunity for the manifestation of Christian neighbourly love, creation 
of inclusive communities, caring for creation and struggling for justice. These are crucial Christian tenets that show the Gospel in action through the diaconal ministry of the church.

\section{Stemming the Tide of Islamic Militancy through Christian Diaconia}

Kjell Nordstokke (2014:65) has argued that the concept of diaconia (diakonia) developed in the course of church history, and it has been strongly impacted by the diaconal movement initiated in Germany in the 1830s with its focus on providing health and social services. In finding a theological grounding for the diaconal practice, biblical material was addressed, especially passages that contain the so-called diak-words (diakonein, diakonia and diakonoc), which often are translated as serve, service and servant, respectively. Diaconal movement scholars like Kittel (1935), have interpreted these words as "active Christian love of the neighbor" (Nordstokke 2014:65; cf. Kittel 1935). Christian diaconia is therefore rooted in the Gospel teaching according to which the love of God and the neighbour are a direct consequence of faith. As such the diaconal mission of the church and the duty of each of its members to serve are intimately bound up with the very notion of the church and stem from the example of the sacrifice of our Lord Himself, our High Priest, who, in accordance with the Father's will "did not come to be served but to serve and to give up his life as a ransom for many" (Matthew. 20:28) (Ecumenical documents nd:175,176). In deriving its essence from the example of Christ and as an indispensable attribute of the community of faith, the ultimate goal of Christian diaconia is the salvation of humankind from everything which oppresses, enslaves, intimidates, destroys and distorts the image of God, and in doing so, to open the way to salvation. This understanding of diaconia inevitably calls the Christian community to a life of individual and cooperate sacrifice, self-denial and sometimes even martyrdom. The ministry of Christian diaconia ministers to the Christian community and to all who come within range of its knowledge and loving care. The object of Christian diaconia is to overcome evil, by offering deliverance from oppression and injustice. For this reason, diaconia is an essential element that sustains the life and growth of the church (Ecumenical documents nd:176,177).

Based on the tenets of the concept of Christian diaconia, the Christian community in Nigeria and Kenya could effectively mobilise its resources to minister to its fold now facing death, persecution, oppression, intimidation, marginalisation and other forms of injustice. Through the same concept the church could even in the mist of its own pain and suffering fulfil its very nature as creation carer and God's agent by ministering to non-Christians and the agents of terror, their families and communities. The concept of Christian diaconia offers the Nigerian and Kenyan Christian community a vital ecclesial paradigm that if properly engaged within the ecumenical, denominational, congregational and individual levels could assist the Christian community in ministering to the needs of the members of the community and to the larger society. Without undermining the enormous task of fulfilling such an ambitious endeavour in the Nigerian and Kenyan society given the religious, socio-political and economic challenges being posed by Boko Haram and Al-Shabaab, such a diaconal ministry could assist in fostering neighbourly love, building of inclusive communities, caring for creation and struggling for justice. These components that are integral to the nature of the church and its diaconal ministry are needed now more than ever in Africa.

\subsection{Diaconia of Neighbourly Love}

The diaconia of neighbourly love requires transforming faith into action. This process requires asking time and again, "who is my neighbour?" (Luke 10:29-37). It also involves individual Christians and Christian communities placing themselves at the disposal of the marginalised, the persecuted, the suffering, the hungry, the thirsty, the sick/wounded and the stranger (Muslim, enemy or terrorist) by asking the question: What do you want me to do for you? (Matthew 25:35-46) (Church of Norway nd:7). Loving and caring for our neighbour involves our whole being and should be based on reciprocity, equality and respect for the integrity of the other. The mutual dependence of human beings requires that throughout life humans should be met with love and compassion. The practical show of love and compassion may sometimes involve small, simple acts. It may also involve major and demanding efforts (Church of Norway nd:7,13).

Aarhus Johannes Nissen (2014:39) has pointed out that the manifestation of neighbourly love in the story of the Good Samaritan could only be possible through seeing, having compassion and acting. What this means is that it is not sufficient to detect those who are suffering by studying statistics or reports of suffering people. 
Since these persons are flesh and blood (real people), the weight of their real conditions can only be more appreciated by seeing with our own eyes. Secondly, the experiences of the suffering requires more than pity, it requires compassion. Compassion goes far beyond pity; it bridges the gap between perception and effective action. Thirdly, the Samaritan "went to him" (the afflicted). It could thus be noted that it was only when all the tree actions were carried out that the Samaritan was able to do what he did.

The diaconia of neighbourly love calls for the Christian church in Nigeria and Kenya through its ecumenical, denominational, congregational and individual capacities to respond to the challenges of all persons being affected by the acts of terror by Boko Haram, Al-Shabaab and other forms of militant Islam. Such persons include Christians, non-Christians, Muslims, members of Boko Haram, Al-Shabaab and their supporters. Such a diaconia requires the specialised ministry of deacons (ordained and non-ordained) and other volunteers drawn from all over Nigeria, Kenya and beyond with skills and provisions that can assist them to minister to the needs of the afflicted. It requires that these "deacons" visit the places and persons being affected. It is also crucial that the diaconia of neighbourly love be inculcated into all Christians and the practice of it should become the Christian lifestyle. Besides bring healing to the recipients and perpetrators of violence, such a lifestyle could assist in building inclusive communities.

\subsection{Building Inclusive Communities through Christian Diaconia}

The Christian community is fundamentally an inclusive community marked by hospitality (Johannes Nissen 2014:41) which has the potential of transmitting its nature to the larger society. The notion of building an inclusive community implies that there are persons that are outside of the community by some reasons which may be cultural, religious, gender, socio-political or economic. Such persons are seen as "strangers". Johannes Nissen (2014:42) has therefore argued that in today's context the "stranger" includes not only the people unknown to us, the poor and the exploited, but also those who are ethnically, culturally and religiously "others" to us. The willingness of the Christian community to accept others in their "otherness" is the hallmark of true hospitality and a pertinent step towards building inclusive communities.

In contexts such as Nigeria and Kenya where religious, ethnic, socio-political and economic divisions are deeply entrenched, building inclusive communities has become indispensable. The challenge of religious otherness between Muslims and Christians is the main driver of terrorism and its consequences. While such experiences of terrorism might create suspicion and hate on the part of the victims and indeed deserves much reflection, it is pertinent to note that an important item of Christian teaching is that we are created to live in fellowship with one another. It is therefore a diaconal responsibility to strengthen relationships between people and to establish new ones when existing relationships break up. Some of the important component s of healthy communities is that they are diverse, inclusive and they offer everyone the opportunity to give and to receive (Church of Norway Plan nd:16-18). For the grace of God manifested in Christ calls the Christian to an attitude of hospitality that is not limited to those who belong to the same group but extends to loving even the enemies (Johannes Nissen 2014:44).To successfully carry out a diaconia of building inclusive communities, teachings that could challenge the ideology of militant Islam but also such that can counter fear and suspicion within various religious communities and justice and reconciliation are crucial.

\subsection{Diaconia of Justice and Reconciliation}

The early Christians aimed at constructing a community which in itself was an example of a just society (Johannes Nissen 2014:45). In a society where there is wanton killing of human beings by terrorists, security agents and persons who claim self-defence, the church must show solidarity and join all persons experiencing injustice in the struggle for justice. In fulfilling the diaconia of justice, the church must be a critical voice against all manifestations of injustice and must also meet the challenges posed by these issues through programmes and projects (Church of Norway n.d:20). Such programmes and projects must begin from the Christian community and should flow into the wider society. In this regard, a diaconia of justice must work for the just distribution of the world's resources among Christians and the larger society within the local context and beyond, through financial support by donor agencies and empowerment schemes. Such a diaconia will also support people whose dignity is violated through pastoral care, trauma counselling, awareness campaigns, support groups, etc. Such endeavours should also be accompanied by non-violence, peace, reconciliation, legal actions against perpetrators of injustice and preventive measures. Justice and reconciliation are inseparable. 
Reconciliation is an on-going process aimed at overcoming estrangement. It is rapprochement in-depth as a result of genuine conversation, argument, discussion and debate (Higginson 2009:44). Reconciliation is about transforming dehumanising situations and their personal and social consequences. Social reconciliation is only possible when a community recovers its dignity and honour. It requires that the human rights abuses are brought to light so that victims can tell their stories, be heard, grieve and gain the support of their communities, and for the perpetrators to admit to their abuses. According to Beyers Naude (1991:227), "No healing is possible without reconciliation, and no reconciliation is possible without justice, and no justice is possible without some form of genuine restitution". In Nigeria and Kenya, diaconia of justice and reconciliation must begin within the Christian fold and their respective ethnic groups and must progress to the adherents of Islam and ultimately to the groups of militant Islam. An approach to reconciliation and justice directed at the Christian community itself will deal with issues pertaining to denominational differences and ethnic suspicions which are deeply entrenched in the Nigerian and Kenyan society. The diaconia of justice and reconciliation can then proceed to the adherents of Islam and Islamic militant groups.

Christian diaconia of justice and reconciliation will have to build synergy with government and civil society (Higginson 2009) to ensure adequate security for Christians and other vulnerable persons. By engaging ecclesial institutional power in tandem with government, the Christian diaconia of justice and reconciliation will have to ensure that government fulfils its responsibility of protecting its citizens from terrorism and intimidation (Romans 13:3). In the same vein, diaconial collaboration with civil society through the institutional power of the church will ensure that publicity is made and civil actions will be engaged to bring to the notice of the Nigerian society and beyond all forms of threats and actions that are tantamount to human rights abuses against Christians. Where the church feels the government and its security operatives cannot or is failing to protect Christians from terrorists, the church's diaconia of justice should be at liberty to explore responsible measures that can assist Christians to obtain security services for their lives and property. Christians like other citizens have a right to self-defence where they face conditions that perpetually place them in danger and insecurity (Higginson 2009). As an important component of the Christian diaconia of justice, all Christians serving in executive, legislative and security arms of government must be encouraged to be sensitive to the security situation of the nation and must be committed to their responsibilities to the state, the Christian community and other citizens.

\section{Conclusion}

Boko Haram, Al-Shabaab and the supporters of militant Islam appear to have declared war against Christians in Nigeria and Kenya and the church is suffering a high level of casualties. This war of militant Islam is arguably driven by a religious agenda: Islamisation of Nigeria and Kenya through the introduction of strict sharia legal system aimed at the subjugation of Christians as second-class citizens or the obliteration of Christianity through persecution, intimidation and martyrdom. The response of the church so far although commendable, still lacks the capacity to contain the crisis, enable the healing and flourishing of the church and forestall the emergence of such crisis in Nigeria and Kenya, in the future. A creative strategy that is theologically and ideologically embedded in the very nature of the church has become inevitable. Such a strategy must incorporate the present mode of the churches engagement but must assist the church to go beyond its present scope. The new strategy suggested in this paper includes the deliberate use of the concept of Christian diaconia through the diaconia of neighbourly love, building of inclusive communities and struggling for justice and reconciliation. Such strategy of Christian engagement initiated by Church leaders in contemporary Nigeria and Kenya could mitigate the impact of the crisis of Boko Haram and Al-Shabaab to the benefit of Christians, Muslims and the entire Nigerian and Kenyan society. Although Jihad is still a paramount raison d'e^tre for alShabaab and Boko Haram, the groups are increasingly being seen as an ordinary struggle for power between different movements where ideologies count for less than power and the struggle of these organisations to create territories and to wrestle political power from existing governments within the areas of their operation (Marchal 2009:399). Yet, the capacity of these groups to cause greater socio-economic and political destruction in Africa cannot be underestimated. 


\section{Acknowledgement}

This material is based upon work supported by the National Research Foundation (NRF) of South Africa under grant Nos. 88489 and 85113. Any opinions, findings and conclusions or recommendations expressed in this material are those of the authors and therefore the NRF does not accept liability in regard thereto.

\section{References}

[1] J. N. Aarhus, "Creating a space for the others: the marginalised as a challenge to Diaconia and church- a theological perspective," Diaconia, vol. 5, pp. 31-46, 2014.

[2] M.S. Abubakar, "You and your Muslim neighbour," presented at a seminar of the National Executive Committee (NEC) of the Christian Association of Nigeria (CAN), Abuja, March 20, 2010.

[3] D. E. Agbiboa, "The Nigerian burden: religious identity, conflict and the current terrorism of Boko Haram", Conflict Security \& Development, vol. 13, no.1, 2013, pp.1-29. DOI:10.1080/14678802.2013.770257.

http://dx.doi.org/10.1080/14678802.2013.770257

[4] O. M. Agbiji, "Development-oriented church leadership in post-military Nigeria: A sustainable transformational approach," PhD dissertation, Stellenbosch University, Stellenbosch, South Africa, 2012.

[5] G. Alexander, 2013. "Dozens die as Islamic militants attack Kenyan shopping mall," The Guardian 2013, viewed 9 September 2015 Available: http://www.theguardian.com/world/2013/sep/21/kenyan-shopping-mall-attack-dead

[6] America. "Nigerian bishops plead for peace and dialogue," America: The National Catholic Review, 7-14 June 6, 2004, viewed 24 January 2011, Available: http://business.highbeam.com/410107/article-1G1-119186151/nigerian-bishopsplead-peace-and-dialogue

[7] J. Carson, "US Official: Violence in Nigeria isn't about religion," Daily Trust, April 6, 2012.

[8] Christian Association of Nigeria (CAN), "Communique of 2nd General Assembly," in Religion in a secular state: Proceedings of the Second Assembly of the Christian Association of Nigeria, A. O. Makozi and G. J. A. Ojo Eds. Abuja, Nigeria: CAN, 1988, pp. 48-50.

[9] Christian Association of Nigeria (CAN), Constitution of the Christian Association of Nigeria, Abuja: CAN, 2004.

[10] Christian Association of Nigeria (CAN), Brief story of the Christian Association of Nigeria, Abuja: CAN, 2010.

[11] Christian Association of Nigeria (CAN), "Christian Association of Nigeria gives final call to Federal Government on violence against Christians," viewed 7 February 2014, Available: http://cannigeria.org/christians-association-of-nigeriagives-final-call-to-federal-govt-on-violence-against-christains/

[12] Christian Association of Nigeria (CAN), "CAN tasks politicians on tolerance, peace in 2014," viewed 3 March 3, 2014, Available: http://www.informationng.com/tag/christian-association-of-nigeria 2014a.

[13] Christian Association of Nigeria (CAN), "Leaders should be elected based on competence, not religion - CAN," viewed March 3, 2014, from http://www.informationng.com/tag/christian-association-of-nigeria 2014b.

[14] Christian Association of Nigeria (CAN), "CAN youth wing decries recent killing of students in Yobe," viewed March 3, 2014, from http://www.informationng.com/tag/christian-association-of-nigeria 2014c.

[15] Church of Norway National Council. Church of Norway plan for diakonia. Oslo: Church of Norway Information Service, viewed August 19, 2014, Available: http://www.kirken.no/english/doc/engelsk/Plan_diakonia2_english.pdf.

[16] K. Cronin, "Behind the Curve: Globalization and International Terrorism," International Security, vol. 27, no. 3, 2002, pp. 30-58.

[17]B. Dachs, "Christians in Kenya 'living in fear' after latest Islamist attack," Catholic Herald, 2014, viewed September 8, 2015, Available: http://www.catholicherald.co.uk/news/2014/12/08/christians-in-kenya-living-in-fear-after-latestislamist-attack/

[18] J. W. de Gruchy, Christian community, in Doing Theology in Context: South African Perspectives. Maryknoll, NY: Orbis Books, 1994.

[19] Ecumenical Document, Church and service: An Orthodox approach to diaconia, 2014.

[20]L. Githaiga, "Diakonia-Kenya," viewed September, 1, 2015, Available: http://www.diakonia.se/en/Where-wework/Africa/Kenya/2013.

[21] L. S. Graybill, Religion and resistance politics in South Africa, Westport: Praeger, 1995. 
[22] J. Harnischfeger, "Boko Haram and its Muslim critics: Observations from Yobe State" in Boko Haram: Islamism, politics, security and the state in Nigeria, M. de Montclos, Ed. Leiden: African Studies centre, 2014, pp. 33-62.

[23]P. Hidalgo, "Kenya's Own Worst Enemy," Foreign Affairs, viewed September 8, 2015, Available: https://www.foreignaffairs.com/articles/kenya/2015-04-12/kenyas-own-worst-enemy 2015.

[24]P. Hidalgo, “Al Shabab's Last Stand?” Foreign Affairs, viewed September 8, 2015, Available: https://www.foreignaffairs.com/articles/kenya/2014-09-11/al-shababs-last-stand 2014.

[25] F. C. Higginson, "Diakonia as a case study in Christian non-violent social action for peace and social justice in South Africa 1976-1982," MA dissertation, University of KwaZulu-Natal, KwaZulu-Natal, South Africa.

[26] S. B. Hobolt, et al. « Religious intolerance and Euroscepticism" European Union Politics, vol. 0, no.0, 2014, pp.1-21. DOI: $10.1177 / 1465116511404620$.

http://dx.doi.org/10.1177/1465116511404620

[27]D. Hughes and M. Bennett, God of the poor: A Biblical vision of God's present rule. Cumbria: OM Publishing, 1998.

[28] Human Rights Watch Report, "Spiralling violence: Boko Haram attacks and security force abuses in Nigeria," viewed August 22, 2014, Available: http://www.hrw.org/sites/default/files/reports/nigeria1012webwcover_0.pdf 2012.

[29] E. Huovinen, "Diaconia - a basic task of the Church," Pro Ecclesia vol. 3, no. 2, 1994, pp. 206-214.

[30]L. R. Iannaccone and E. Berman, "Religious extremism, the good, the bad, and the deadly," Public Choice, 2006, 128:109-129, DOI: 10.1007/s11127-006-9047-7

http://dx.doi.org/10.1007/s11127-006-9047-7

[31]W. Kigotho, "Churches accuse Muslim scholars of 'inaction' over attack. University," World News, viewed September 8, 2015, Available: http://www.universityworldnews.com/article.php?story=20150423163242805

[32] B. Kwashi, "Conflict, suffering and peace in Nigeria," Transformation Journal, vol. 21, no. 1, 2004, pp. 60-69.

[33]H. G. Mang, «Christian perceptions of Islam and society in relation to Boko Haram and recent events in Jos and northern Nigeria" in Boko Haram: Islamism, politics, security and the state in Nigeria, M. de Montclos, Ed. Leiden: African Studies centre, 2014, pp. 85-109.

[34] R. Marchal, “A tentative assessment of the Somali Harakat Al-Shabaab," Journal of Eastern African Studies, vol.3, no. 3, 2009, pp. 381-404.

[35] A. Meleagrou-Hitchens, "Jihad comes to Kenya: Interview with a militant," Foreign Affairs, 2013, viewed September 17, 2015, Available: https://www.foreignaffairs.com/articles/kenya/2013.../jihad-comes-kenya

[36] J. Meservey, "Terrorist Turf Wars:Why al Shabab Attacked Kenya's Garissa University College" Foreign Affairs, viewed September 8, 2015, Available: https://www.foreignaffairs.com/articles/kenya/2015-04-07/terrorist-turf-wars

[37] K. Mohammed, "The Message and methods of Boko Haram" in Boko Haram: Islamism, politics, security and the state in Nigeria, M. de Montclos, Ed. Leiden: African Studies centre, 2014, pp. 9-32.

[38] T. M. Monsma, Hope for the Southern world: Impacting societal problems in the non-Western world, Loveland: CCW Books, 2006.

[39] H. Mwakimako, "Christian-Muslim Relations in Kenya: A Catalogue of Events and Meanings," Islam and ChristianMuslim Relations, vol. 18, no. 2, April 2007, pp. 287-307.

[40] B. Naude, "The role of the Church in a changing South Africa", in L. Alberts et al (eds), 1991.

[41] K. Nordstokke, "Diakonia according to the Gospel of John," Diaconia, vol. 5, 2014, pp. 65-76.

[42]F. Nzwili, “After attacks, Kenyan Muslims guard Christian churches," The Christian Science Monitor, 2012, viewed on September 9, 2015, Available: http://www.csmonitor.com/World/Africa/2012/0710/After-attacks-KenyanMuslims-guard-Christian-churches

[43] E. Obadare, "In search of a public sphere: the fundamentalist challenge to civil society in Nigeria," Patterns of Prejudice, vol. 38, no. 2, 2004, pp.177-198.

[44] M. A. Oduyoye, Hearing and knowing: Theological reflections on Christianity in Africa, Maryknoll: Orbis Books, 1986.

[45] A. Olojo, "Nigeria's troubled North: Interrogating the drivers of public support for Boko Haram," viewed 5 August 2014, Available: http://www.icct.nl/download/file/ICCT-Olojo-Nigerias-Troubled-North-October-2013.pdf

[46] P. A. Omayio, "Keeping Religion out of a Conflict: Learning from the Kenyan Church," International Journal of Sociology and Anthropology, vol. 7, no. 2, 2015, pp. 38-45. 
[47]P. A. Omayio, "The Response of the church in Nairobi to the Al-Shabaab Terror Attacks: A case study of St. Polycarp Anglican Church Juja Road Pangani and God's House of Miracles International Nairobi," Master's Thesis, MF Norwegian School of Theology, Oslo, 2014.

[48] J. Onaiyekan, "Dividends of religion in Nigeria," Unpublished public lecture presented at the University of Ilorin, Ilorin, Nigeria, May 12, 2010.

[49]U. A. Onwunta, "Ethnicity and missional strategies within the Presbyterian Church of Nigeria," PhD Doctoral Dissertation, Stellenbosch 2006.

[50]K. M. Otiso, "Kenya in the Crosshairs of Global Terrorism: Fighting Terrorism at the Periphery," Kenya Studies Review, vol. 1, no. 1, 2009, pp. 107-132.

[51]J. Otubu, "Church leader urges prayers to tackle Boko Haram, insecurity" viewed August 21, 2014, Available: http://allafrica.com/stories/201408200452.html

[52] "Popular Discourses of Salafi Radicalism and Salafi Counter-radicalism in Nigeria: A case study of Boko Haram," Journal of Religion in Africa, vol. No. 42, 2012, pp. 118-144.

[53] S. P. Pretorius, "Religious cults, religious leaders and the abuse of power," International Journal for Religious Freedom, vol. 6, nos. 1/2, 2013, pp. 203-215.

[54]N. Smart, Dimensions of the sacred: An anatomy of the world's beliefs, Berkeley and Los Angeles: University of California Press, 1996.

[55]I. Swart, The churches and the development debate: Perspectives on a fourth generation approach, Stellenbosch: SUN Press, 2006.

[56]C. O. Williams, "General Secretary's report," in Religion in a secular state: Proceedings of the Second Assembly of the Christian Association of Nigeria, A. O. Makozi \& G. J. A. Ojo Eds., Abuja: CAN, 1988, pp. 10-12.

[57] S. Zaimov, "Nigeria: 4 Churches Burned Down, Scores Killed in Deadly Boko Haram Attack on Christians," viewed August 21, 2014, Available: http://www.christianpost.com/news/nigeria-4-churches-burned-down-scores-killed-indeadly-boko-haram-attack-on-christians-122439/\#

[58] J. Zenn, "Leadership analysis of Boko Haram and Ansaru in Nigeria," CTC Sentinel vol. 7, no. 2, 2014, pp. $23-29$. 